ISSN 0258-7122

Bangladesh J. Agril. Res. 37(1): 159-169, March 2012

\title{
EFFECT OF DIFFERENT HEDGEROW SPECIES AND NITROGEN LEVEL ON THE SOIL PROPERTIES AND YIELD OF OKRA (Abelmoschus esculentus L. Moench)
}

\author{
Z. A. FIROZ ${ }^{1}$, K. M. NASIRUDDIN ${ }^{2}$ AND M. F. MONDAL ${ }^{2}$
}

\begin{abstract}
An experiment was conducted at the Hill Agricultural Research Station, Khagrachari from June 2002 to November 2004 to find out the effect of hedgerow species (Ipil-ipil, Indigofera, Pigeon pea , Pineapple with control) and different nitrogen levels (50, 75, and 100\% recommended dose of $\mathrm{N}$ ) on the soil properties and yield of okra in hill slope condition during the rainy season. Different soil properties were affected by hedgerow species and $\mathrm{N}$ level with okra crop. In maximum cases, Indigofera with $100 \% \mathrm{~N}$ showed better performance. The highest $\mathrm{pH}$ value 6.0 , total nitrogen content 0.84 , available phosphorus 4.4, exchangeable calcium $1.27 \mathrm{meq} / 100 \mathrm{~g}$, exchangeable sulphur $12.8 \mathrm{meq} / 100 \mathrm{~g}$, and CEC 21.5 were recorded from Indigofera with $100 \% \mathrm{~N}$. The most satisfactory okra yield 15.05 t/ha was in Indigofera $+100 \% \mathrm{~N}$ that was statistically at par with Indigofera $+75 \% \mathrm{~N}$.
\end{abstract}

Keywords: Hedgerow species, nitrogen level, soil properties, okra yield.

\section{Introduction}

Okra (Abelmoschus esculentus L. Moench) is an annual vegetable crop in tropical and sub-tropical parts of the world (Thakur and Arora, 1986). It is one of the important nutritious vegetable crops grown round the year in Bangladesh. Its every $100 \mathrm{~g}$ green pod contains protein $1.8 \mathrm{~g}$, carbohydrate $6.4 \mathrm{~g}$, fibre $1.2 \mathrm{~g}$, Vitamin C $18 \mathrm{mg}$, and Ca $90 \mathrm{mg}$ (Rashid, 1999). There is crucial need to increase vegetable production during the rainy season through proper management techniques or introducing new rainy season vegetables. Okra as a summer/rainy season vegetable can play a vital role in this regard.

Upland ecosystem of Bangladesh comprises considerable area which is characterized by low soil fertility and crop productivity. The subsistence farmers often do not use costly fertilizers and other inputs for crop production. It is important to develop viable farming system that will allow sustainable level of food production by maintaining soil fertility. Hedgerow intercropping/alley cropping could be a sound technology for sustainable crop production. During the cropping period, pruned materials obtained from different hedgerow species are incorporated to the soil in order to improve the soil physio-chemical properties and ultimately improve the growth and development of associate crops

${ }^{1}$ Regional Agricultural Research Station, Hathazari, Chittagong, ${ }^{2}$ Bangladesh Agricultural University (BAU), Mymensingh, Bangladesh. 
(Miah, 1993). Gliricidia sepium, Leucaena leuocosepala, Indigofera tysmanii are the most suitable tree species that are used widely in the alley cropping system throughout the world. Sometimes agronomic crop hedgerow like pineapple and pegionpea are used as hedgerow to control run off and soil erosion in the hilly region (Firoz and Uddin, 2001). Hedgerow plants are recommended for cultivation in hill slope because hedgerow plants are effective in controlling soil erosion and reducing run off (Khisa, 2001).

Nitrogen level and organic contents in the hill tracts are very poor. On the other hand, farmers in this area do not use appropriate dose of fertilizers in their field because of their least technological knowledge and poor economical condition (Ahmad, 2001). Use of nitrogen fertilizer can be saved through this system as $\mathrm{N}$ is added to the soil through leaf/root decomposition. It may also be considered as a suitable technology both economically and environmentally. So investigation was undertaken to select suitable hedgerow species and nitrogen level to increase soil fertility and for better production of okra in hill slope condition.

\section{Materials and Method}

The experiment was conducted at the Hill Agricultural Research Station, Khagrachari from June 2002 to November 2004. A 5 x 3 x 3 split plot design with three replications was followed. The main plot treatments were 4 types of hedgerow species with control. These were: Ipil-ipil (Leucaena leucocepala), Indigofera (Indigofera trysmonii), Pigeon pea (Cajanus cajan), and Pineapple (Ananus coronus). The treatments in the sub-plot consisted of different nitrogen levels (\%) as $\mathrm{N}_{50}(50 \%$ recommended dose of $\mathrm{N}), \mathrm{N}_{75}$ (75\% recommended dose of $\mathrm{N}$ ), and $\mathrm{N}_{100}$ (100\% recommended dose of $\mathrm{N}$ ) and recommended dose of $\mathrm{N}$ was $100 \mathrm{~kg} / \mathrm{ha}$. The unit plot size was $3.0 \times 2.4 \mathrm{~m}$. The plot and blocks were separated by $0.5 \mathrm{~m}$ and $1.0 \mathrm{~m}$, respectively. Seeds of okra were sown on 03 July 2004 at a spacing $60 \times 40 \mathrm{~cm} .100 \mathrm{~kg}$ TSP and $150 \mathrm{~kg} \mathrm{MP} / \mathrm{ha}$ were also used. Cowdung was used @ 10 t/ha during land preparation. Intercultural operations were done as and when necessary. Harvesting of fruits started from 20 August and continued up to 30 October 2004. Soil samples were collected from different locations of the experimental plots before start of the experiment. After harvesting of crop, soil samples were collected again. Soil was collected at the depth of $0-20 \mathrm{~cm}$. The samples were allowed to dry in open air, mashed and then analyzed to determine $\mathrm{N}, \mathrm{P}, \mathrm{K}, \mathrm{Ca}, \mathrm{Mg}, \mathrm{S}, \mathrm{CEC}$ in the laboratory of BARI, Gazipur. Data of yield was recorded on plot basis. Collected data were subjected to statistical analysis by F-test and the difference between the treatments means were judged by Duncan's Multiple Range Test (DMRT).

\section{Hedgerow establishment and management}

Before the establishment of the hedgerow, the land was fallow and full of various grasses. Seeds of different hedgerow were collected from "Slopping Agricultural 
Land Technology (SALT) model farm at Allotila, Khagrachari (Established by Upland Settlement Project of Hill Tracts Development Board). Seedlings of Indigofera and Ipil-ipil were raised in polyebag nursed for about 3 months. The seedlings were transplanted during August 2002 and adequate management practices were done to establish the seedlings. Seeds of pigeonpea and suckers of pineapple were also planted at the same time. Plant to plant distance was $50 \mathrm{~cm}$ for Indigofera and 1pil-ipil and for pigeon pea and pineapple was $30 \mathrm{~cm}$. Distance between 2 hedgerows (alley width) was $3 \mathrm{~m}$.

Indigofera, Ipil-ipil,and pigeonpea were pruned above $1 \mathrm{~m}$ from ground and all pruned materials were used in the soil as well as mulch and green manure from one month before sowing of okra seeds. Pruning materials were weighed for calculating the amount of total biomass added to the soil. Only the leaves and soft portion of upper twigs from the pruning were used as biomass. The woody stems more than $2 \mathrm{~cm}$ diameter were removed and laid out horizontally at the base of the hedgerow. The hedgerows were pruned 6 times before starting okra cultivation. Since, the growth of all species was rapid in crop season due to rains, the tree species was again pruned 2 times at the vegetative stage of okra to minimize the competition for light and also for biomass harvesting. Pineapple and pigeonpea were used as food crop hedgerow to control soil erosion.

\section{Results and Discussion}

\section{Changes in soil properties}

The effect of the experimental treatments on some selected soil chemical properties in the topsoil $(0-20 \mathrm{~cm})$ layer are presented in Fig. I - Fig. 9. The soil chemical properties, such as soil $\mathrm{pH}$, organic matter $(\mathrm{OM})$, total nitrogen $(\mathrm{N})$, available phosphorus (P), exchangeable potassium (K), calcium (Ca), Magnesium (Mg), Sulphur (S), and cation exchange capacity (CEC) were studied over time to observe the actual change due to treatment effect.

\section{Soil pH}

The soil $\mathrm{pH}$ gives an indication of the degree of availability of many nutrients and favourable soil condition to microbial activity. Many essential elements are available when soil $\mathrm{pH}$ is just little below or upper the natural scale $(\mathrm{pH} 7.0)$. Figure 1 shows that the soil $\mathrm{pH}$ with different hedgerow species $+\mathrm{N}$ level associated with okra crop was affected by pruning. It was noted that $\mathrm{pH}$ increased in all hedgerow treatments compared to control and initial $\mathrm{pH}$. The highest soil $\mathrm{pH}$ value (6.0) was recorded in Indigofera $+100 \% \mathrm{~N}$ and the lowest was observed in control plot $+50 \% \mathrm{~N}$ (5.5). The increase soil pH under Indigofera may be explained by its faster decomposition. Similar increases in soil $\mathrm{pH}$ under hedgerow species was observed by Attakrah and Sumberg, 1988, and Gavine, 1999 which is in conformity with the findings of the present study. 


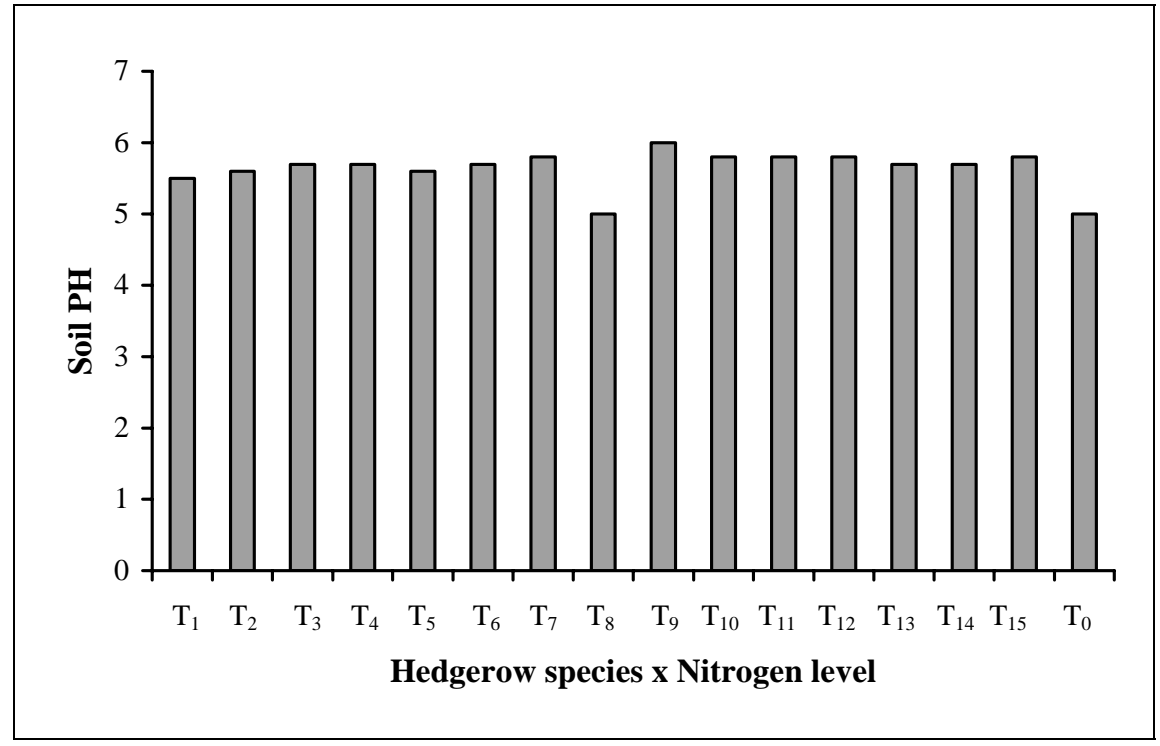

Fig. 1. Soil pH of topsoil layer from 24 month old hedgerow species and associations with okra as influenced by hedgerows and different nitrogen levels.

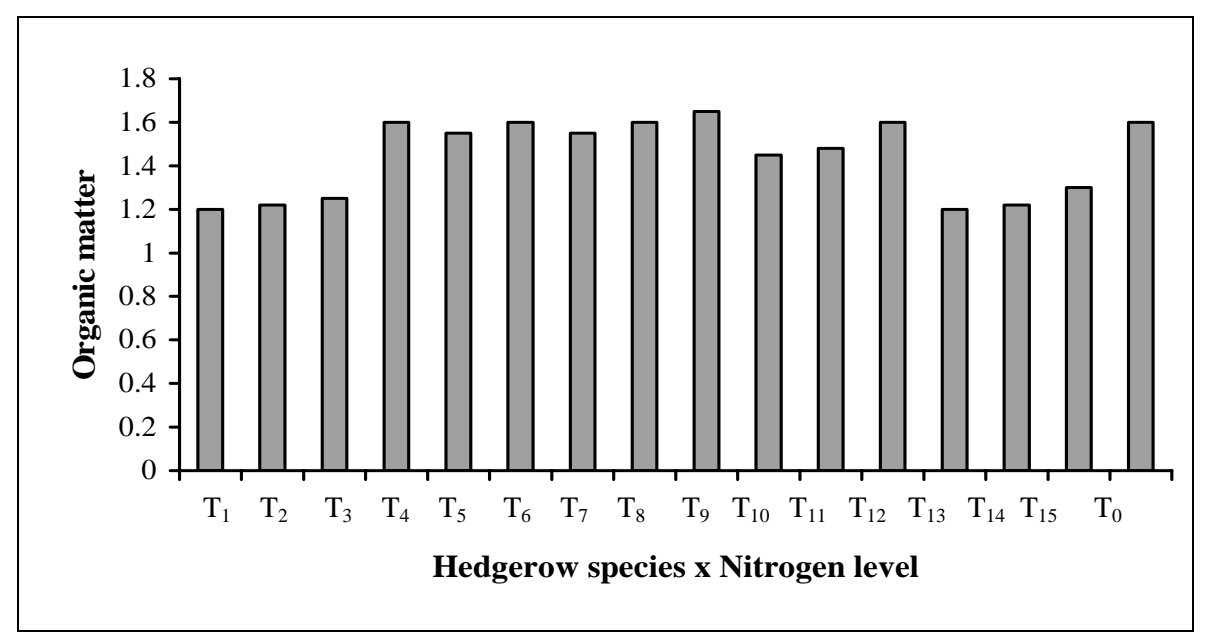

Fig. 2. Soil OM of topsoil layer from 24 month old hedgerow species and associations with okra as influenced by hedgerows and different nitrogen levels.

$\mathrm{T}_{\mathrm{I}}=$ Control $+50 \% \mathrm{~N}, \mathrm{~T}_{2}=$ Control $+75 \% \mathrm{~N}, \mathrm{~T}_{3}=$ Control $+100 \% \mathrm{~N} \mathrm{~T}_{4}=$ Ipil-ipil $+50 \% \mathrm{~N}, \mathrm{~T}_{5}=$ Ipilipil $+75 \% \mathrm{~N}, \mathrm{~T}_{6}=$ Ipil-ipil $+100 \% \mathrm{~N}, \mathrm{~T}_{7=}$ Indigofera $+50 \% \mathrm{~N}, \mathrm{~T}_{8}=$ Indigofera $+75 \% \mathrm{~N}, \mathrm{~T}_{9}=$ Indigofera $+100 \% \mathrm{~N}, \mathrm{~T}_{10}=$ Pigeonpea $50 \% \mathrm{~N}, \mathrm{~T}_{11}=$ Pigeonpea $75 \% \mathrm{~N}, \mathrm{~T}_{12}=$ Pigeonpea $100 \% \mathrm{~N}, \mathrm{~T}_{13}=$ Pineapple $50 \% \mathrm{~N}, \mathrm{~T}_{14}=$ Pineapple $75 \% \mathrm{~N}, \mathrm{~T}_{15}=$ Pineapple $100 \% \mathrm{~N}$, To=Initial stage 


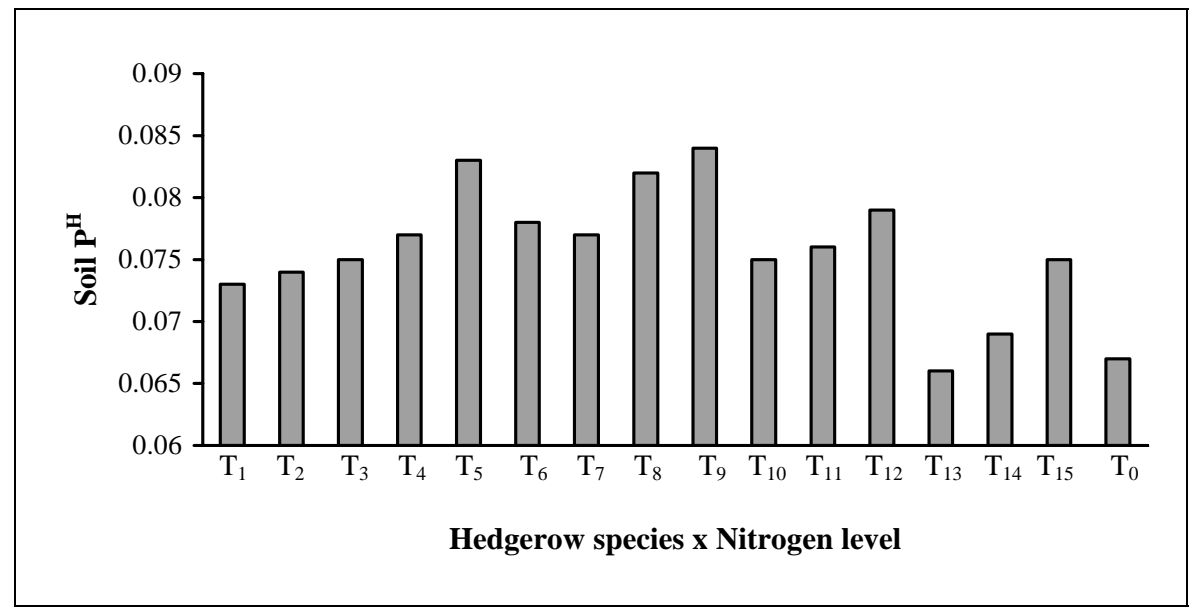

Fig. 3. Total nitrogen content from 24 month old hedgerow species and associations with okra as influenced by hedgerows and different nitrogen levels

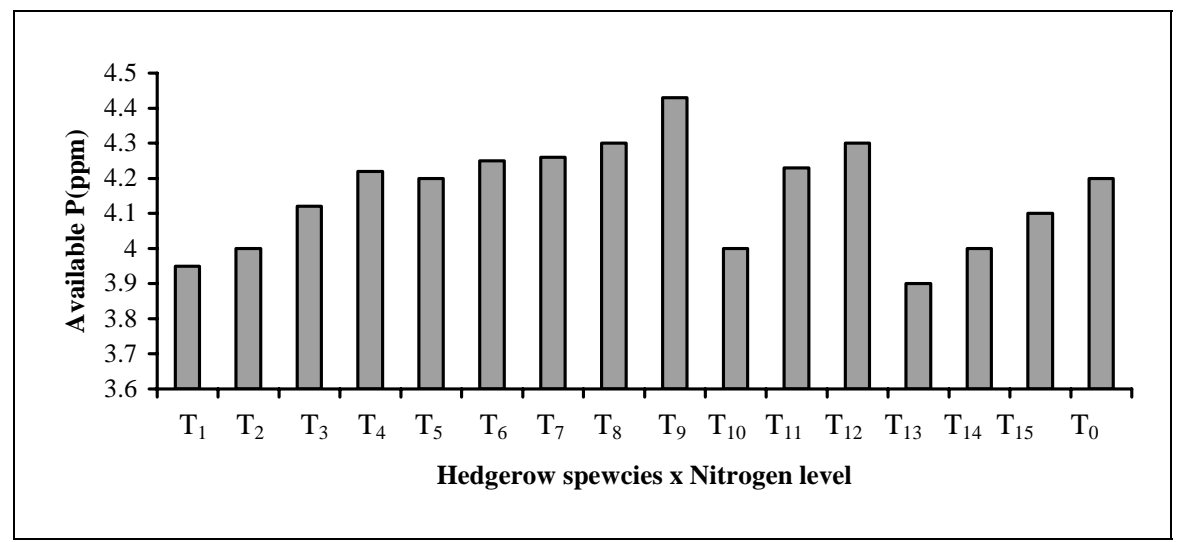

Fig. 4. Available P (ppm) content from 24 month old hedgerow species and associations with okra as influenced by hedgerows and different nitrogen level

$\mathrm{T}_{\mathrm{I}}=$ Control $+50 \% \mathrm{oN}, \mathrm{T}_{2}=$ Control $+75 \% \mathrm{~N}, \mathrm{~T}_{3}=$ Control $+100 \% \mathrm{~N} \mathrm{~T}=$ Ipil-ipil $+50 \% \mathrm{~N}, \mathrm{~T}_{5}=$ Ipil-ipil $+75 \% \mathrm{~N}, \mathrm{~T}_{6}=1$ pil-ipil $+100 \% \mathrm{oN}, \mathrm{T}_{7}=$ Indigofera $+50 \% \mathrm{~N}, \mathrm{~T}_{8}=$ Indigofera $+75 \% \mathrm{~N}$, $\mathrm{T}_{9}=$ Indigofera $+100 \% \mathrm{~N}, \mathrm{~T}_{10}=$ Pigeonpea $50 \% \mathrm{~N}, \mathrm{~T}_{11}=$ Pigeonpea $75 \% \mathrm{~N}, \mathrm{~T}_{12}=$ Pigeonpea $100 \% \mathrm{~N}, \mathrm{~T}_{13}=$ Pineapple $50 \% \mathrm{~N}, \mathrm{~T}_{14}=$ Pineapple $75 \% \mathrm{~N}, \mathrm{~T}_{15}=$ Pineapple $100 \% \mathrm{~N}, \mathrm{~T}_{0}=1$ nitial stage

\section{Organic matter (OM)}

The organic matter content of soil is an important parameter in relation to soil fertility management. OM has beneficial effects on soil physical and chemical properties (Nair, 1990, and Young, 1991). Soil organic matter showed an 
increasing trend in all the treatments over control except pineapple (Fig. 2). It was significantly higher in Indigofera with all levels of $\mathrm{N}$ and Ipil-Ipil and pigeon pea with $100 \% \mathrm{~N}$. It was slightly lower in control plot and pineapple hedgerow plots as against initial OM content. The increased OM content could be attributed to the addition of large quantities of pruned material biomass in the legume hedgerow treatments.

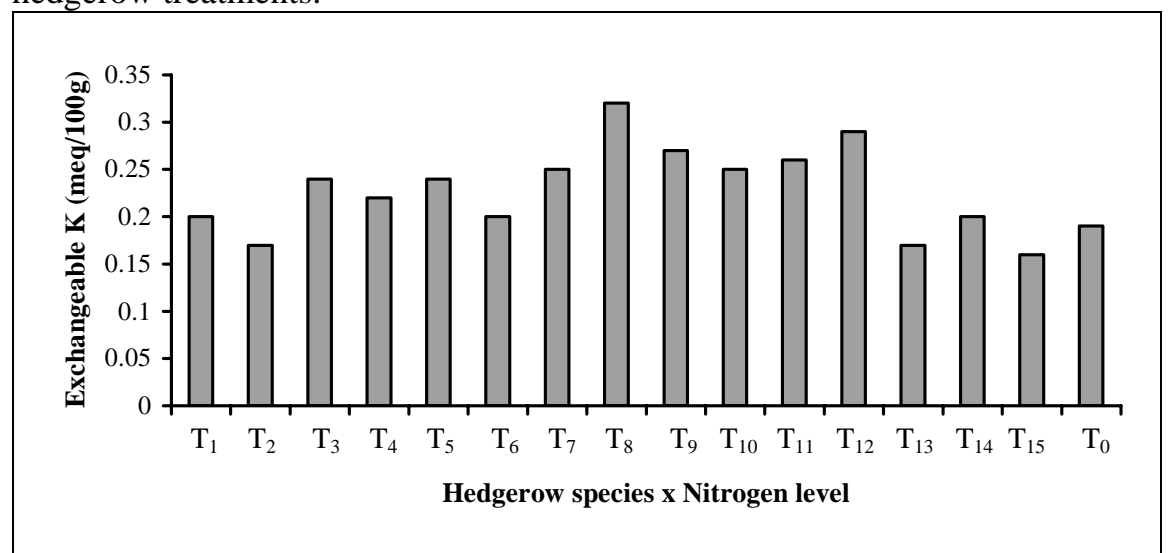

Fig. 5. Exchangeable $\mathrm{K}$ content at topsoil from 24 month-old hedgerow species andassociations with okra as influenced by hedgerows and nitrogen levels.

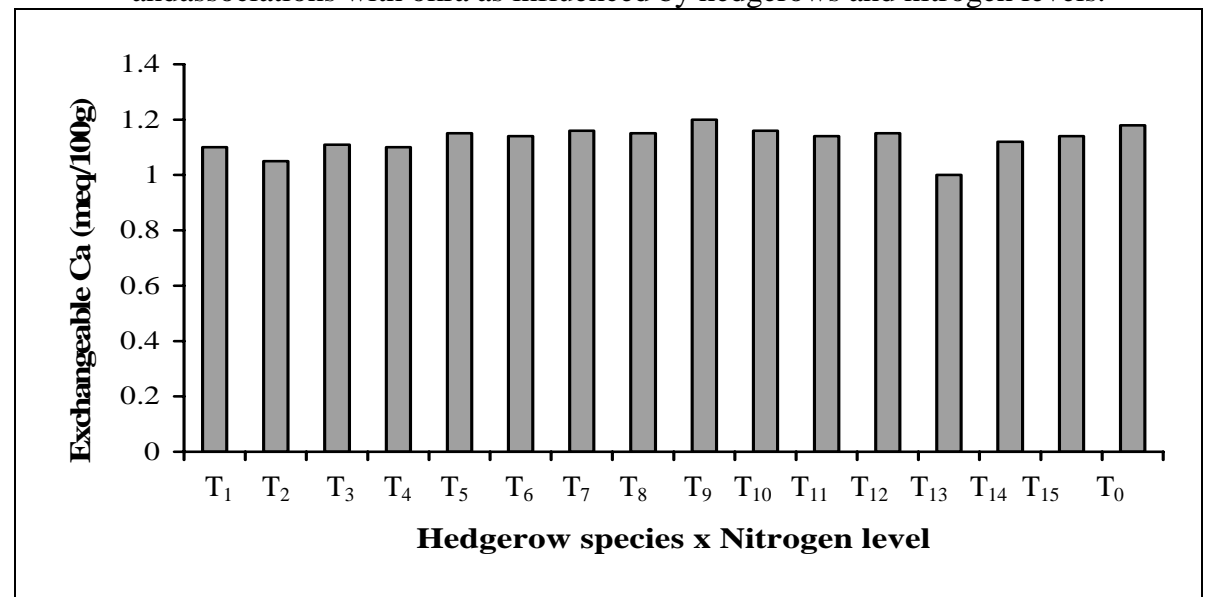

Fig. 6. Exchangeable Ca content at topsoil from 24 month old hedgerow species and associations with okra as influenced by hedgerows and nitrogen levels.

$\mathrm{T}_{\mathrm{I}}=$ Control $+50 \% \mathrm{~N},{ }_{2}=$ Control $+75 \% \mathrm{~N}, \mathrm{~T}_{3}=$ Control $+100 \% \mathrm{~N} \mathrm{~T} \mathrm{~T}_{4}=$ Ipil-ipil $+50 \% \mathrm{~N}, \mathrm{~T}_{5}=$ Ipil-ipil $+75 \% \mathrm{~N}, \mathrm{~T}_{6}=$ Ipil-ipil $+100 \% \mathrm{~N}, \mathrm{~T}_{7}=$ Indigofera $+50 \% \mathrm{~N}, \mathrm{~T}_{8}=$ Indigofera $+75 \% \mathrm{~N}, \mathrm{~T}_{9}=$ ndigofera $+100 \% \mathrm{~N}, \mathrm{~T}_{10}=$ Pigeonpea $50 \% \mathrm{~N}, \mathrm{~T}_{11}=$ Pigeonpea $75 \% \mathrm{~N}, \mathrm{~T}_{12}=$ Pigeonpea $100 \% \mathrm{~N}, \mathrm{~T}_{13}=$ Pineapple $50 \% \mathrm{~N}, \mathrm{~T}_{14}=$ Pineapple $75 \% \mathrm{~N}, \mathrm{~T}_{15}=$ Pineapple $100 \% \mathrm{~N}, \mathrm{~T}_{0}=$ Initial stage 


\section{Total nitrogen}

Soil $\mathrm{N}$ content followed a trend similar to that of OM (Fig. 3). The highest total $\mathrm{N}$ content (0.84) was found in Indigofera $+100 \% \mathrm{~N}$ and the lowest content $(0.70)$ was in Pineapple $+50 \% \mathrm{~N}$. Total $\mathrm{N}$ content in control plots decreased as compared to legume hedgerow plots as well as initial plots. Increased $\mathrm{N}$ content of the surface soil with leguminous trees was reported by Getahun and Jama (1989).

\section{Available phosphorus (P)}

Available phosphorus means the portion of the total soil phosphorus which can be utilized by plants. Most of the natural ecosystem, P level of soil is low. The experimental results revealed that in most of the cases $\mathrm{P}$ content increased over initial stage but in few cases it decreased (Fig. 4). Among the treatments $\mathrm{P}$ was 3.96, 4.01, and 4.11 in control plot; 4.23, 4.20, and 4.27 in Ipil ipil, 4.29, 4.42, 4.25, 4.28 in pigeon pea, and 3.88, 3.92, 4.27 in pineapple (50, 75, and $100 \% \mathrm{~N}$, respectively). The present findings are in agreement with that of Gonzal and Raros, (1987), Lasco (1991), and Miah et al. (1993).

\section{Exchangeable K}

Potassium availability in the soil depends largely on the density of standing biomass. The exchangeable $\mathrm{K}$ content of the topsoil of 24 month old 3 species were grown with vegetable crop okra is presented in Fig.5. The exchangeable K was slightly lower in pineapple plots compared to control and legume plots.

\section{Exchangeable calcium (Ca)}

Soil contents of exchangeable Ca showed an increasing trend in all the treatments (Fig. 6). Before conducting the experiment, the exchangeable Ca content on the soil was $1.09 \mathrm{meq} / 100 \mathrm{~g}$, but after 24 months it varied from 1.08-1.27 meq/100 g soil. The data showed that Ca content on the control plots was almost same before and after conducting the experiment. It was the highest in Indigofera + $100 \% \mathrm{~N}$ and the lowest in control plot $+50 \% \mathrm{~N}$.

\section{Exchangeable magnesium (Mg)}

The trend in sole exchangeable $\mathrm{Mg}$ content was different from those of other soil nutrients (Fig. 7). Exchangeable Mg content in soil was slightly decreased in all treatments over initial plots. A similar decrease in soil exchangeable Mg was reported by Soriano (1991). But Onim et al. (1990) reported no effect of soil Mg contents before and after conducting the experiment. 


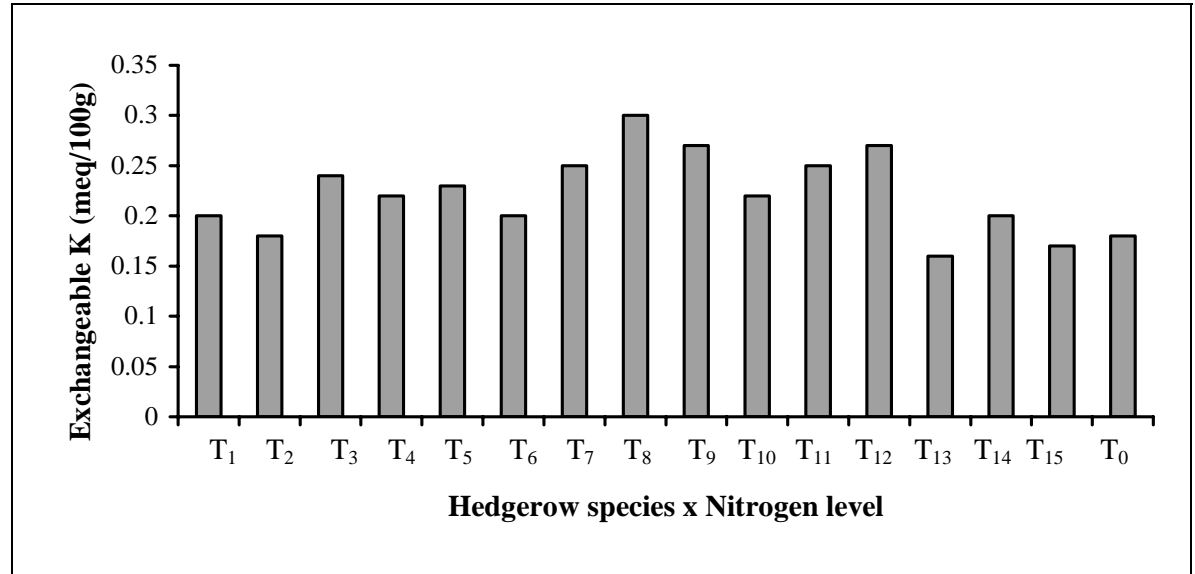

Fig.7. Exchangeable Mg content at topsoil from 24 months-old hedgerow species and associations with okra as influenced by hedgerows and nitrogen levels.

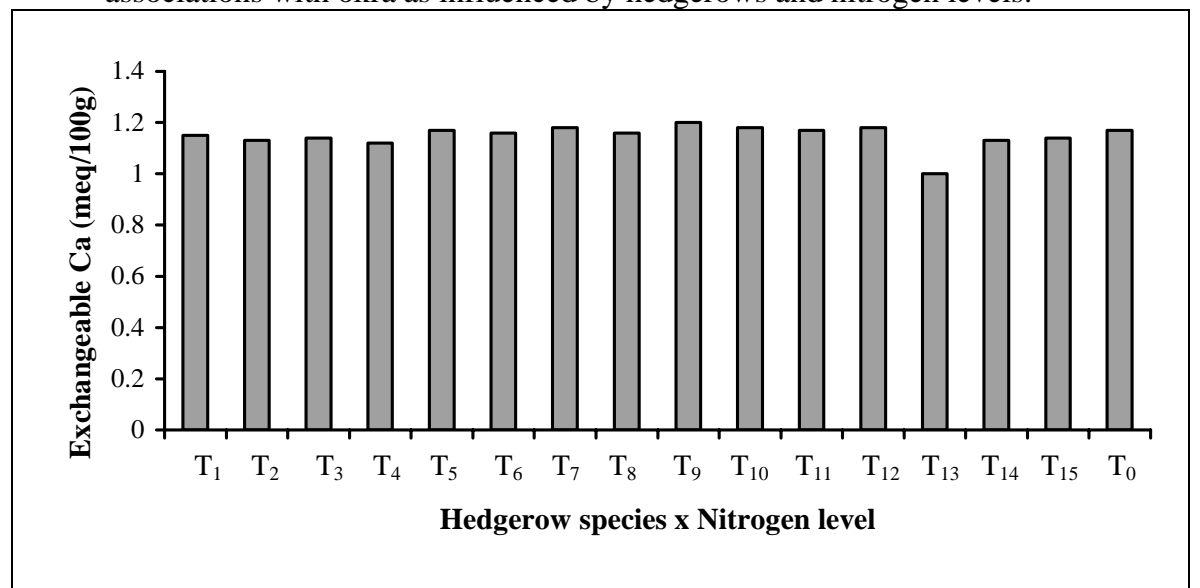

Fig. 8. Exchangeable S (meq/100g) content at topsoil from 24 month old hedgerow and associations with okra as influenced by hedgerows and nitrogen levels.

$\mathrm{T}_{\mathrm{I}}=$ Control $+50 \% \mathrm{oN}, \mathrm{T}_{2}=$ Control $+75 \% \mathrm{~N}, \mathrm{~T}_{3}=$ Control $+100 \% \mathrm{~N} \mathrm{~T}_{4}=$ Ipil-ipil $+50 \% \mathrm{~N}, \mathrm{~T}_{5}=$ lPil-ipil $+75 \% \mathrm{~N}, \mathrm{~T}_{6}=1$ pil-ipil $+100 \% \mathrm{oN}, \mathrm{T}_{7}=$ Indigofera $+50 \% \mathrm{~N}, \mathrm{~T}_{8}=$ Indigofera $+75 \% \mathrm{~N}$, $\mathrm{T}_{9}=$ Indigofera $+100 \% \mathrm{~N}, \mathrm{~T}_{10}=$ Pigeonpea $50 \% \mathrm{~N}, \mathrm{~T}_{11}=$ Pigeonpea $75 \% \mathrm{~N}, \mathrm{~T}_{12}=$ Pigeonpea $100 \% \mathrm{~N}, \mathrm{~T}_{13}=$ Pineapple $50 \% \mathrm{~N}, \mathrm{~T}_{14}=$ Pineapple $75 \% \mathrm{~N}, \mathrm{~T}_{15}=$ Pineapple $100 \% \mathrm{~N}, \mathrm{To}=$ Initial stage.

\section{Exchangeable sulphur (S)}

Fig. 8 shows that in all treatments $\mathrm{S}$ content was increased after completion of the experiment. It ranged from 10.8 to 12.8 whereas in initial stage, it was 10 . Like other nutrients, it was maximum in Indigofera $+100 \%$ N (12.8 meq/100g 
soil) followed by same hedgerow species with 75 and $50 \% \mathrm{~N}$. The lowest S content was in control plot $+50 \% \mathrm{~N}$ level.

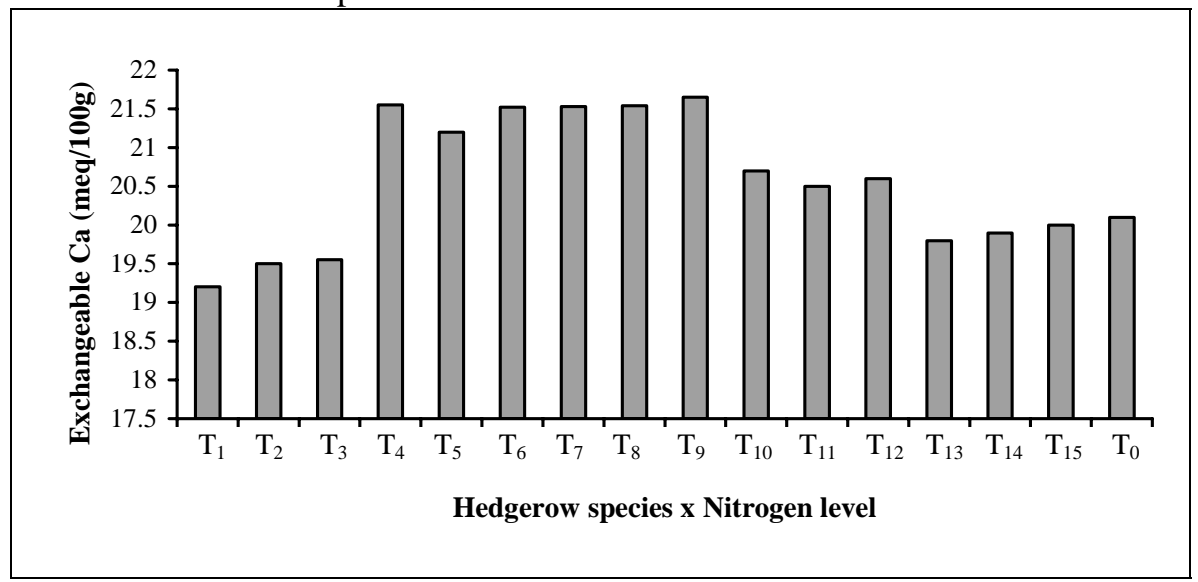

Fig. 9. Cataion Exchange capacity (meq/100g) content at topsoil from 24 months old hedgerow species and associations with okra as influenced by hedgerows and nitrogen levels.

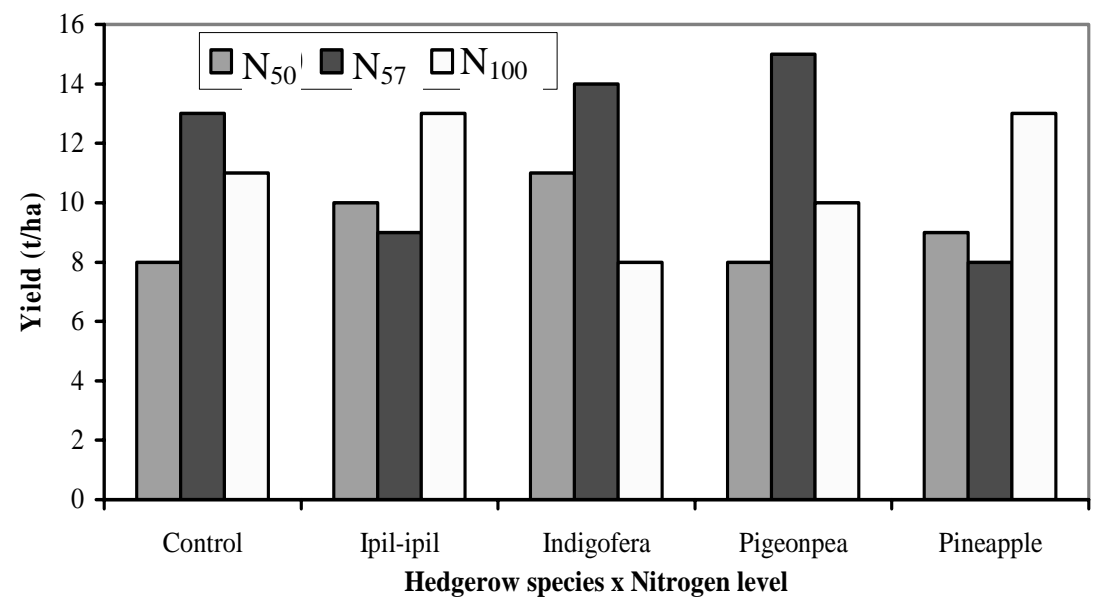

Fig.10. Effect of different hedgerow species and different nitrogen level on the yield (t/ha) okra.

$\mathrm{T}_{\mathrm{I}}=$ Control $+50 \% \mathrm{oN}, \mathrm{T}_{2}=$ Control $+75 \% \mathrm{~N}, \mathrm{~T}_{3}=$ Control $+100 \% \mathrm{~N} \mathrm{~T}_{4}=$ Ipil-ipil $+50 \% \mathrm{~N}, \mathrm{~T}_{5}=$ lPilipil $+75 \%$ oN, $\mathrm{T}_{6}=1$ pil-ipil $+100 \% \mathrm{oN}, \mathrm{T}_{7}=$ Indigofera $+50 \% \mathrm{~N}, \mathrm{~T}_{8}=$ Indigofera $+75 \% \mathrm{~N}$, $\mathrm{T}_{9}=$ ndigofera $+100 \% \mathrm{~N}, \mathrm{~T}_{10}=$ Pigeonpea $50 \% \mathrm{~N}, \mathrm{~T}_{11}=$ Pigeonpea $75 \% \mathrm{~N}, \mathrm{~T}_{12}=$ Pigeonpea $100 \% \mathrm{~N}, \mathrm{~T}_{13}=$ Pineapple $50 \% \mathrm{~N}, \mathrm{~T}_{14}=$ Pineapple $75 \% \mathrm{oN}, \mathrm{T}_{15}=$ Pineapple $100 \% \mathrm{oN} \mathrm{To}=$ Initial stage 


\section{Cation exchange capacity (CEC)}

The CEC of the topsoil of experiential plot did not vary much before and after conducting the experiment (Fig. 9). The CEC in the control plot and pineapple plot slightly decreased and slightly increased in other legume hedgerow plots.

\section{Yield of okra ( $t / h a)$}

The most satisfactory yield (15.05 t/ha) was in Indigofera $+100 \% \mathrm{~N}$ that was statistically at par with Indigofera $+75 \% \mathrm{~N}$ (Fig. 10). The highest fresh pruning material was in Indigefera which was much more higher than Ipil ipil and pigeon pea. Dry pruning material was also higher in Indigofera followed by Ipil ipil and pigeonpea. The treatment combination Indigofera $+100 \% \mathrm{~N}$ got maximum amount of nitrogen and biomass than other treatment combinations. As a result the treatment Indigofera $+100 \% \mathrm{~N}$ produced the highest yield.

\section{References}

Ahmad, N. U. 2001. Performance of upland rice in alley cropping system at different levels of nitrogen. MS Thesis. Dept. of Agroforestry and Environment, Bangabandhu Sheikh Mujibur Rahman Agril. Univ., Gazipur, Bangadesh.

Atta-Krah, A. N. and I. E. Sumberg. 1988. Studies with Gliricidium sepium for crop/livestock production systems. Agrofor. Syst. 6 (2): 97-118.

Firoz, Z.A. and M.S. Uddin.2001. Establishment of a model farm with intensified land management for crop production in hill slope. Proc. National Workshop on Agroforestry Research, Gazipur, Septemberl 6-17. pp. 199-20 1.

Gavin, L. B. 1999. Preliminary assessment of nutrient contents of soil under Gricidia sapium. Nitrogen Fixing Tree Research Reports 7: 49.

Getahun, A. and B. Jama. 1989. Alley cropping in the coastal area of Kenya. In: Proc. of Workshop on Alley Farming in the Humid and Sub humid Tropics, Ibadan, Nigeria, March 10-14. pp. 156-164

Gonzal, D. G. and R. S. Raros. 1987. Effect of Gliricidia sepium mulch on up land rice yield and fertility. In: Proc. of an international workshop on multipurpose tree species for small farm use, Pattaya, Thailand, November 2-5. pp. 261-264.

Khisa, S. K. 2001. Contour hedgerow inter-cropping agroforestry technology for degraded hillside farms in Chittagong hill tracts. In: Proc. National workshop of Agroforestry Research, Gazipur, Septemberl6-17. pp. 179-184.

Lasco, R. D. 1991. Herbage decomposition of some agroforetry species and their effect as mulch on soil properties and crop yield. Ph. D. Dissert., UPLB College of Forestry.

Miah, M. G. 1993. Performance of selected multipurpose tree species and field crops grown in association as affected by tree branch pruning. Ph. D. dissert. (Crop Science-Agronomy), CLSU, Philippines. 
Nair, P. K. R. 1990. The Prospect of Agroforestry in the Tropics. Kluwer Academic Publisher, London.

Onim, J. F. M., M. Mathauva, K. Otieno and Fitzhugh. 1990. Soil fertility changes and response to maize and bean to green manure of Laucaena, sesbania and pigeonpea. Agrofor. Syst. 12: 197-215.

Rashid, M.M. 1999. Sabji Biggan (Vegetables Science). $2^{\text {nd }}$ edition, Rashid Publishing House, Dhaka.

Soriano, H. M. Jr. 1991. Soil fertility and productivity aspects of alley cropping schemes using leguminous trees as hedgerows and corn (Zea mays L.) as an alley crop. Ph. D. dissert, UPLB, Laguna.

Thakur, M. R. and S. K. Arora. 1986. Okra. In: Vegetable Crops in India. Bose, T. K. and M. G. Som (ed), Naya Prokash, Calcutta, pp. 610-618.

Young, A. 1991. Soil fertility. In: Biophysical Research for Asian Agroforestry. Avery, M.E., M. G. R. Cannel and C. Ong (eds). Winrock International, USA and South Asia Books, USA, pp. 292. 